\begin{tabular}{|l|l|l||}
\hline \multicolumn{2}{|c|}{ PublisherInfo } \\
\hline \hline PublisherName & $:$ & BioMed Central \\
\hline \hline PublisherLocation & $:$ & London \\
\hline \hline PublisherImprintName & $:$ & BioMed Central \\
\hline \hline
\end{tabular}

\title{
Two for the price of one
}

\begin{tabular}{|l|l|l||}
\hline \multicolumn{2}{|c|}{ ArticleInfo } \\
\hline \hline ArticleID & $:$ & 3842 \\
\hline \hline ArticleDOI & $:$ & $10.1186 /$ gb-spotlight-20001124-01 \\
\hline \hline ArticleCitationID & $:$ & spotlight-20001124-01 \\
\hline \hline ArticleSequenceNumber & $:$ & 279 \\
\hline \hline ArticleCategory & $:$ & Research news \\
\hline ArticleFirstPage & $:$ & 1 \\
\hline \hline ArticleLastPage & $:$ & 2 \\
\hline \hline & & RegistrationDate : 2000-11-24 \\
ArticleHistory & $:$ & OnlineDate $\quad 2000-11-24$ \\
\hline \hline ArticleCopyright & $:$ & BioMed Central Ltd2000 \\
\hline \hline ArticleGrants & $:$ & \\
\hline \hline ArticleContext & $:$ & 130591111 \\
\hline \hline
\end{tabular}




\section{Jonathan Weitzman}

Email: jonathanweitzman@hotmail.com

The nuclear-encoded RNA polymerase RpoT;2 from Arabidopsis thaliana differs from the polymerases that transcribe the plant's nuclear genes and resembles RNA polymerases from bacteriophages. In the 15 November EMBO Reports, Hedtke et al. describe the use of GFP (green fluorescent protein) fusion proteins to examine the subcellular localization of RpoT;2 (EMBO Reports 2000, 1:435-440). The RpoT;2 transit peptide targeted GFP fusion proteins to both mitochondrial and chloroplast compartments in tobacco protoplasts and transgenic Arabidopsis plants. RpoT;2 may therefore be able to transcribe genes from two different genomes. This is in contrast to two other phagetype RNA polymerases from Arabidopsis, which are exclusively targeted to either mitochondria (RpoT;1) or chloroplasts (RpoT;3).

\section{References}

1. EMBO Reports, [http://www.embo-reports.oupjournals.org]

2. GFP applications page, [http://pantheon.cis.yale.edu/ wfm5/gfp_gateway.html]

This PDF file was created after publication. 